\title{
The Discovery of Alsatian Space in the Regionalist Art Historiography of the First Half of the $2^{\text {th }}$ Century
}

\author{
Valentin TRIFESCU \\ Babeş-Bolyai University, Cluj-Napoca \\ Strasbourg University \\ valentintrifescu@yahoo.fr
}

\begin{abstract}
Our paper tries to analyse the way in which the regional identity of art historiography in Alsace came into being in the $20^{\text {th }}$ century. Similarly to Transylvania, Alsace represented a highly disputed territory, being claimed by two hostile nations. We shall focus upon the regionalist point of view, which used to be overshadowed by the official nationalist discourse of the centres, Paris and Berlin. We shall examine the way in which a regional identity was invented through works of art. Regionalist art historians did no longer speak of the existence of French or German art in Alsace, but of the existence of an Alsatian art individualized within European art. We shall also emphasise the role the genius loci and regional geography played in forging this new identity.
\end{abstract}

Keywords: regional identity, art historiography, Alsace, regional geography

To Corina Moldovan

\section{Natural borders}

The extraordinary influence of Vidal de la Blache's writings (1845-1918) was not limited to the circle of geographers only, but it spread among art historians as well. Beside the analysis of different kinds of artefacts and monuments, regional geography enjoyed a large popularity among regionalist art historians. Artistic works were placed in the immediate geographical context, thus developing new meanings. In addition to that, a tight connection was observed between the geographical area and the work of art, the latter one being influenced by or completed with the peculiarities of landforms. In this way, a new kind of art history was established in which, based on the idea that artistic geographies are influenced by the environment, the plastic and conceptual message of the artistic 
productions was strongly determined by the landforms: mountains, hills, plains, valleys, rivers.

Even though most often Vidal de la Blache's ideas were not explicitly formulated in Alsatian art historians' texts in the first half of the $20^{\text {th }}$ century, there are also cases in which Vidal's approach was assumed from the very beginning. For instance, it is quite eloquent for us how some historians and Alsatian art critics chose to start their scientific studies citing names of geographers. This is the case of Raymond Régamey (1900-1996) (Régamey 1925: 3) and of Claude Odilé (1881-1957), to give just two examples at hand. The latter developed Vidal's considerations over several pages, adapting them to the specific needs that the study of architectural monuments and of the ethnographic heritage in Alsace require. The main idea that emerged from here was that, geographically, Alsace is part of both Central and Mediterranean Europe; the territory between the Vosges and the Rhine being depicted as "real European crossroads", which goes beyond the limited interests of two nations (Odilé 1934: 7-9). Thus, the perception of Alsace's specific artistic and cultural identity started form a geographical / geological approach. Locating this historical province on the map of the continent meant to describe its particular historical status. The fact that it is placed at the confluence of several "tectonic plaques" implicitly determined a considerable number of cultural influences.

It is interesting to see how Claude Odilé reads this territory by invoking Vidal de la Blache. Alsace was not seen as a neutral territory, without any historical or geographical personality. Being located on the border, it was part neither of France nor of Germany. In other words, no regional West-East perspective of the territory was assumed, i.e. a nationalist French or German perspective. The geographical outlook was considerably enlarged by including Southern Italy in the palette of geographic and cultural influences. It is also notable that the Alsatian art historian did not exclude the German influences from Alsace, on the contrary, he catalogued them as bearing a great significance. According to Claude Odilé "It is impossible to live in Strasbourg without feeling simultaneously attracted to two poles: the Mediterranean and the other. This other one being the German pole in the case of the Alsatians" (Odilé 1934: 7). ${ }^{1}$ Nevertheless, the Francophile perspective contributed with some cultural and ethnographic evidence to justify Alsace's geographical inclusion in the French territory. In fact, the French national character was invoked, which obviously differs from the German way of being, especially regarding its extraordinary capacity to assimilate and integrate foreign elements, a quality which does not characterize the Germans. "And here is once again Vidal de la Blache who led me to this. 'France, he said, is a land which seems to have been made to absorb its own emigration.' An admirable definition.

1 "[...] Il est impossible de vivre à Strasbourg sans se sentir attiré vers ces deux pôles à la fois: le méditerranée et l'autre. L'autre, pour les Alsaciens, c'est le pôle allemand [...]" [The French quotations have been translated into English by Enikő Pál.] 
If Germany were in this situation, we would risk being on the verge of a European war" (Odilé $1934: 7$ ). ${ }^{2}$

Whether the views were of more or less regionalist or Francophile nature, references to the geography of Alsace have constantly been present in the writings of Alsatian art historians. Landforms became important not only because they offered Alsace a physical aspect and a moral personality, but they also left their mark on the works of art giving them new potentials through the specific climate and lights (Ahnne 1950: 7).

According to André Hallays (1859-1930), Alsace has a well-defined geographical personality outlined by landforms for which it can be distinguished within the general setting of France:

No province of France has a geographical individuality as well defined as Alsace. It borders the Rhine River in the east, the Vosges Mountains in the west, in the south it is marked by the watersheds between the Rhone and the Rhine basin and, lastly, it borders the Jura foothills. It is only its northern boundary which fluctuated according to the vicissitudes of history: once it was marked by the Queich Valley, in 1815 being moved to Lauter. ${ }^{3}$ (Hallays 1929: 5)

One may detect an almost obsessive concern to identify even the most insignificant geographical coordinates in order to draw the precise contours of Alsace, which is detectable during the evocation of the two minor tributaries of the Rhine which, compared to the Vosges or to the great river, gain a caricaturelike aspect. Hallays dealt with the lack of major landforms in northern Alsace, which would visibly close the regional geographic area, by resorting to a trick. According to the author, the fluctuating boundaries in the north were due to the whims of political-military history, which destabilized the existence of a particular geographical stability of the borders.

In 1917, in an article dedicated to Alsatian folk art, the idea of an Alsace which is perfectly surrounded and enclosed by the main landforms was expressed by Anselme Laugel (1851-1928). According to the scholar, a refugee in France after the Franco-Prussian War until 1918, the homeland was considered to be one

2 “[...] Et c'est encore Vidal de la Blache qui m'y conduit. 'La France, dit-il, est une terre qui semble faite pour absorber sa propre émigration'. Admirable définition. Si l'Allemagne se trouvait dans cette situation, nous ne risquerions point de guerre européenne."

3 “Aucune province de France n'a une individualité géographique aussi tranchée que l'Alsace. Elle est limitée au levant par le cours du Rhin, au couchant par la chaîne des Vosges, au midi par la ligne des partages des eaux entre le bassin du Rhône et celui du Rhin et par les derniers contreforts du Jura. C'est seulement au nord que sa frontière a oscillé selon les vicissitudes de l'histoire: formée autrefois par la vallée de la Queich, elle a été, en 1815, amenée à celle de la Lauter." 
of the few regions in the world which are so well defined geographically: "the Rhine on one side and the Vosges on the other form a ditch and a bulwark of an admirable clarity" (Laugel 1917: 15). ${ }^{4}$ But the mere display of all the mountains, rivers and valleys was not enough to give a historical and cultural meaning to a province. The interpretation of regional geography offered by Laugel goes beyond this, since the landforms have different meanings and, eventually, are given political connotations. For instance, the mountains united Alsace with France, while the Rhine separated it from Germany. The heights of the Vosges has not been an impediment to maintain or justify the close relationships between Alsace and France, due to the numerous accessible crossing points: Bussang, Schlucht, Bonhomme, Saint-Marie-aux-Mines, Saales or Saverne. The conclusion reached by Anselme Laugel in 1917, while the soldiers of the two rival nations were facing each other on the battlefields of the Great War, was that: "Doesn't this clearly show that Germany has nothing to do in Alsace, and that, on the contrary, the French could freely enter there" (Laugel 1917: 15). ${ }^{5}$

It is surprising that where we would expect the most the idea of a perfect regional geography to be acclaimed, there the approach has been much more reticent and relativized. In other words, although reporting to regional geography was of equal importance in the discourse of some Alsatian regionalist art historians as well, it was done in a different way. As mentioned before, André Hallays seeks to describe with great meticulosity even the smallest rivers, which, in his perspective, harmoniously enclose the geography of Alsace. According to the tricked approach, the regionalist André Hallays only implicitly talks about the topic without any explanation or justification, limiting himself to a "neutral" presentation of some data which give the readers the impression of being about some common places. Robert Heitz (1895-1984) deals with the issue of regional geography in a deconstructive manner. Not geography gave the province cohesion but history. Citing the study of Pierre Marthelot (1909-1995) entitled Géographie humaine de l'Alsace (Marthelot 1947: 9-40), Heitz reinforced the idea that the unity and peculiarity of Alsace were determined first of all by spiritual elements; namely, the awareness of a common identity assumed by the inhabitants of this province, which made Marthelot and Heitz share the idea that "In this respect, Alsace represents indeed - and perhaps more than any other province of France - what Michelet called a 'person"' (Marthelot 1947: 9-40; Heitz 1952: 26). ${ }^{6}$

According to Robert Heitz, it was historical determination that gave unity to Alsace, not the geographical one. In order to prove his statement, the art

4 “[...] le Rhin d'une part, et les Vosges de l'autre forment un fossé et un rempart d'une admirable netteté [...]"

5 “Cela signifie clairement, n'est-il pas vrai ? que l'Allemagne n'a rien à faire en Alsace, et que, par contre, la France peut y entrer librement [...]"

6 “[...] A cet égard, l'Alsace représente bien - et peut-être plus qu'aucune autre province de France - ce que Michelet appelait une "personne»" 
historian from Strasbourg gives a series of relevant examples, exceptions from the rule, which demonstrate that the historical and identitary Alsace does not correspond in all cases to geographical Alsace. No landforms are regarded as borders anymore, Alsace being considered the result of the past's assumption and not a place marked by natural boundaries. Actually, introducing this point of view into discussion, the eternal geographical argument exploded, based on which the French or Germans had made political and territorial demands over Alsace. Accordingly, the Rhine and the Vosges could not be invoked any more as borders par excellence since regional geography has always been fluctuating. Hence, this time Alsace was defined from an inner perspective of those who regard themselves as Alsatians. Heitz claims that:

Indeed the unity and personality of Alsace are given by its historical context rather than its natural condition. Despite appearances, Alsace has no natural boundaries.// Not even the Rhine. It forms the eastern border along $183 \mathrm{~km}$. It should be recalled that the territory lying on the right bank of the river belonged to the Bishopric of Strasbourg for a long time, and then to Napoleon, and that Breisach used to be a French territory for a century and a half and that Kehl valley was attached to Alsace under the Empire. In the west, the Vosges are far from being a precise boundary. Historically and ethnically, the middle and upper parts of the Bruche valley were not part of Alsace: they were attached to it in 1817 after the Treaty of Frankfurt only for strategic reasons. In contrast to this, the same treaty left France the territory of Belfort, a former Alsatian territory. In the north, in 1815, a part of the possessions of Wissembourg Abbey and Landau, fortified by Vauban, were given to Palatine. In the south, we have Mulhouse, a small and insignificant town until recently, which joined Switzerland in the sixteenth century and united with France in 1798. Finally, Alsace Bossue (s'Krumm Elsass), attached to Alsace in 1791 together with Sarre-Union and Drulingen, mainly for religious reasons, is actually a part of the Lorraine plateau (Heitz 1952: 25-26). ${ }^{7}$

$7 \quad$ "En effet l'unité et la personnalité de l'Alsace, qui ne peuvent être discutées, sont le fait moins de la nature que de la détermination historique.// L'Alsace, malgré les apparences, n'a pas des frontières naturelles.// Le Rhin, soit. Il forme la frontière orientale sur un parcours de 183 kilomètres. Convient-il de rappeler que le territoire de l'Évêché de Strasbourg a longtemps, et jusqu'à Napoléon, empiété sur la rive droite du fleuve, que Vieux-Brisach a été français pendant un siècle et demi et que la vallée de Kehl, sous l'Empire, était rattachée à l'Alsace. A l'ouest, les Vosges sont loin de constituer une frontière précise. La vallée moyenne et supérieure de la Bruche n'a pas fait partie, historiquement et ethniquement, de l'Alsace ; elle lui a été incorporée seulement par le Traité de Francfort, en 1817, pour des raisons stratégiques. En revanche, le même traité laissa à la France le territoire de Belfort, ancienne terre alsacienne. Au nord, en 1815, le Palatinat s'est vu attribuer une partie des possessions de l'abbaye de Wissembourg et la place de Landau, fortifiée par Vauban. Au sud, nous avons vu Mulhouse, petite ville assez insignifiante jusqu'à une date récente, quitter l'Alsace pour la Suisse au XVI' siècle et s'unir à la France en 1798. Enfin, l'Alsace «bossue» ou «tortue» (s'Krumm Elsass) avec Sarre-Union et Drulingen, rattaché à l'Alsace en 1791, surtout pour des raisons d'ordre confessionnel, constitue en réalité une partie du plateau lorrain." 


\section{Inner space}

In addition to Alsatian art historians' special interest in tracing the natural borders of Alsace, an equally important concern was to define the regional inner space.

Authors like Robert Heitz or Anselme Laugel constructed their argumentation based on the lyrics-written by Émile Erckmann (1822-1899) and Alexandre Chatrian (1826-1890)—of a famous Alsatian song from the ' 80 s of the $19^{\text {th }}$ century, entitled "Tell me, which is your country?". ${ }^{8}$ Although its message was explicitly Francophile or anti-German-see the confession in its last lines: "Germans, this is my country// What we say is what we do // It would rather change the heart of the place // Than change the old Alsace" ${ }^{\text {- }}$ the regional perspective of the Alsatian territory was only discreetly introduced by a trivial definition which remained in a latent state until it was exploited in a regionalist manner. More precisely, it is the last part of the refrain which briefly defines the inner space of Alsace: "Tell me, which is your country:// Is it France or is it Germany?// It is a country of plains and mountains". ${ }^{10}$ In fact, the lines above eloquently illustrate the specific regionalist ambiguous and diverted discourse, in which only in a primary phase, or perhaps only apparently, the Periphery expresses its sympathy with one or another centre of power.

In order to be better understood, we shall decode the regionalist message of the poem's refrain to which, later on, Anselme Laugel and Robert Heitz related to. The question Which is your country?"-already knowing the end of the poemsong which is unfavorable for Germans-has no explicit answer either in favor of France or of Germany. The answer given by the Alsatian poets (French "patriots") identifies the country from a geographic point of view, defining it as a space with plains and mountains. Actually, it defined nothing else but: Alsace.

The definition of Alsace as "a country with plains and mountains" is quite trivial, it could apply to many other provinces and countries of the globe which, of course, are formed by plains and mountains. However, Anselme Laugel gives these landforms a special charm, suggesting that there is a spirit of the place: "But looking at these plains, crossing these mountains, we shall soon discover their power of attraction uncommonly captivating" (Laugel 1917: 13). ${ }^{11}$

The inner space of Alsace may be described not only by evoking these two extreme landforms: plains and mountains. The vineyard up on the hills became the third defining characteristic of the Alsatian territory which, in this way, gained

8 "Dis-moi, quel est ton pays?"

9 "Allemands voilà mon pays// Quoi que l'on dise quoi que l'on fasse // On changera plutôt le cœur de place// Que de changer la vieille Alsace."

10 "Dis-moi, quel est ton pays:// Est-ce la France ou l'Allemagne ?// C'est un pays de plaines et de montagnes."

11 "Mais examinons ces plaines, parcourons ces montagnes, et nous ne tarderons pas à leur découvrir une puissance d'attraction singulièrement captivante." 
a much more varied aspect. In this tripartite scenery of plains, hills and mountains, the specific Alsatian landscape opens up, on which the local artistic monuments appear like in a regional scenography. With respect to this Laugual claims that:

Between the plains and mountains, there line up a series of hills with vineyards which provide a wine that is not to be despised, a benefic wine which gets along with songs and happiness.// It is in the folds of these famous hills where our most lovely Alsatian towns hide, surrounded by walls and defended by towers which once seemed threatening but now seem to emanate a disturbing balance with their sloping roofs, as hats on ears, on which wallflowers and houseleeks creep shaking and crumbling, which does not make them less attractive, and they seem to be surprised that anyone could take them seriously (Laugel 1917: 14-15). ${ }^{12}$

In the definition of Alsace seen as "a country of plains and mountains" Robert Heitz underlines the word "and" given his desire to emphasize "the simultaneous presence of the mountains and plains" (Heitz 1952: 26-27) in the visual field of the one who contemplates the Alsatian landscape. Hence, the perception of the regional space has become more complete in which all the landforms are simultaneously present forming the specific Alsatian landscape; renouncing the fragmented and gradual presentation of the regional landforms. The Alsatian artistic monuments are profiled on the background of this geography which catches the eye all at once and in all its complexity: "At the entrance of these mountain passes and valleys and especially in the northern Vosges, where the entanglement of some high valleys makes the transition more convenient, there stand the ruins of strongholds followed by watchtowers and Roman castles" (Heitz 1952: 27). ${ }^{13}$

Some other art historians, among which André Hallays and Paul Ahnne (1910-1977), highlighted the extraordinary diversity of Alsatian landscape where mountains, valleys, hills, ravines, rivers, forests and vineyard hills harmoniously meet (Hallays 1929: 6; Ahnne 1950: 7). The inner space of Alsace

12 "Entre la plaine et la montagne, une série de coteaux garnis de vignes fournissent un vin qui n'est pas à dédaigner, vin bienfaisant et qui coexiste aux chansons et aux joyeux propos.// C'est dans les replis de ces coteaux fameux que se cachent nos plus aimables bourgades alsaciennes, ceinturées de murailles et défendues par des tours qui, autrefois, semblaient menaçantes, mais qui, aujourd'hui, coiffées de toits à l'équilibre inquiétant, comme des pochards qui auraient leur chapeau sur l'oreille, couvertes de giroflées et de joubarbes, un peu branlantes et fortement délabrées, n'ont plus rien de rébarbatif, et semblent s'étonner, elles-mêmes, qu'on ait pu, parfois, les prendre au sérieux."

13 "[...] A l'entrée de ces cols et des vallées qui y conduisent, mais surtout dans les Vosges septentrionales, où l'enchevêtrement des vallées peu élevées rend le passage plus commode, se dressent les ruines d'innombrables châteaux forts, succédant aux tours de guet et castels romans." 
was not divided according to historical, political or administrative criteria. None of the great regionalist art historians have ever profiled the artistic and identitary geographies of Alsace based on the two departments of the province: HautRhin and Bas-Rhin. ${ }^{14}$ Moreover, neither political history criteria, which would consider the longer or shorter existence of small principalities and free cities, have ever been taken as reference in art historians' discourses. The approach has always been mainly geographical, discussing the Alsatian landscape and its geographical forms where, ultimately, villages, cities and isolated art monuments have been included. According to this, Alsace was considered to be, by turn and/ or simultaneously:

A country with mountains, vast forests and narrow valleys; a country of plains where roads and rivers are engraved as in some ancient writing, indeed. But it is also a country of hills and tender valleys where small towns and villages are nestled as much as human presence, where the vine climbs to conquer the slopes marking its footprints and giving this impression; a land of agriculture, industry and art where the names Strasbourg, Colmar, Mulhouse sound like many echoes (Ahnne 1950: 7). ${ }^{15}$

The natural environment was sometimes invested with a number of aesthetic virtues becoming an independent work of art such as a painting. Moreover, describing the beauty and richness of landforms led to the appearance of a symbolic dimension of Alsace, i.e. a paradise on earth. For a better understanding of how art historians depicted the artistic monuments in an enchanting and fairylike natural setting, we shall quote the thoughts of André Hallays, who describes nature and art being in a perfect symbiosis where the relationship between space and art is a privileged one: "But no picture is more impressive and more exciting than that one that carries 'frau major' of Moennelstein: the sudden appearance of the plain, villages, steeples; the silver rain and the mountains of the Black Forest making the horizon blue" (Hallays 1929: 6). ${ }^{16}$

14 Although André Hallays' book is entitled Sites et monuments. L'Alsace (le Haut-Rhin - le BasRhin) [Sites and monuments. Alsace (Haut-Rhin - Bas-Rhin)], the inner conception which oriented the judgement of the artistic monuments did not follow the artificial administrative division of Alsace into its two departments.

15 “[...] Pays de montagnes aux vastes forêts et aux vallées étroites ; pays de plaine où les routes, les fleuves et les rivières s'inscrivent comme une écriture très ancienne, certes. Mais aussi pays de coteaux et de tendres vallonnements où les petites villes et les villages sont nichés comme autant de présences humaines, où la vigne grimpe à l'assaut des pentes, les marquant de son empreinte et de cette impression ; terre d'agriculture, d'industrie et d'art où les noms de Strasbourg, de Colmar, de Mulhouse résonnent comme autant d'appels ou comme autant d'échos."

16 “[...] Mais nul tableau n'est plus grandiose, plus émouvant que celui qui transportait la 'frau major' du Moennelstein: la brusque apparition de la plaine, des villages, des clochers; du pleuve d'argent et des monts de la Forêt Noire bleuissant à l'horizon." 
Beside the historical background, the surrounding environment determined Alsatians' particular way of being. The characteristics of landforms-plains, hills and mountains-led to a well-defined range of behaviors and human qualities. Alsatians' life was included and understood in / from the perspective of regional geography. On this occasion, the existence of a genius loci was suggested which determined the moral conduct and attitudes of those who live within the area bound by the Vosges and the Rhine. Last but not least, there can be noticed an attempt to achieve an affective and behavioral gradation depending on the altitude and on the characteristics of the main landforms. This observation is confirmed by Ferdinand Dollinger (1862-1936), an Alsatian scholar with both regionalist and Francophile orientation and editor of the famous magazine of art and culture Revue alsacienne illustrée / Illustrierte elsässische Rundschau [Alsatian illustrated magazine]:

Its soul seems to reflect the contrast between a serious, often tragic, history and its pleasant nature. This nature itself combines, with 'a constant harmony', this opposition which seems less expected: the serenity of the plain, the exuberance of the hills, the contemplation of the mountain; and this harmony is basically the key quality of the race. Alsatians prefer effective actions to words in vain. They hate ostentation as much as hypocrisy. They deal with serious matters with gravity. Their characteristics are strength rather than finesse, tenacity rather than initiative, steadfastness rather than rapidity. They are conscientious, reliable and trustworthy (Dollinger 1929: 117-118). ${ }^{17}$

In his last unfinished text published posthumously, due to his sudden death, Hans Haug does not regard geography and history as two separate entities any more. On the contrary, they overlap and complete each other. According to the art historian from Strasbourg, the Vosges actively contributed to Alsatians' destiny during their history. The relationship between people and the mountains were seen as a direct bond, which went beyond the borders and beyond spiritual, temporal or national characteristics. Additionally, the Vosges became the

17 "On dirait que se reflètent, dans son âme, les contrastes entre une histoire grave, souvent tragique, et une riante nature. Cette nature elle-même associe, dans 'une harmonie sans cesse présente: “[...] Mais nul tableau n’est plus grandiose, plus émouvant que celui qui transportait la 'frau major' du Moennelstein: la brusque apparition de la plaine, des villages, des clochers; du pleuve d'argent et des monts de la Forêt Noire bleuissant à l'horizon", ces oppositions de tons qui frappent les moins avertis : la sérénité de la plaine, l'exubérance des coteaux, le recueillement de la montagne; et cette harmonie est au fond des qualités maîtresses de la race. L'Alsacien aime l'action efficace et hait les vains discours. Il a horreur de l'ostentation comme de l'hypocrisie. Il traite avec gravité les choses sérieuses. Il a plus de solidité que de finesse, plus de ténacité que d'initiative, moins de rapidité de conception que de constance dans l'effort. Il est consciencieux, sûr, fidèle." 
immediate keepers of the regional history by preserving on their peaks the art vestiges-intact ruins and monuments-thus evoking the memory of places, of historical facts and legends: "All this is like a huge living body, swarming with present realities and evocative memories" (Haug 1966: VII). ${ }^{18}$

These external influences of the surrounding environment alone did not draw Alsatians' behavioral and identitary profile. In fact, we might say that, according to some scholars who have written about the art and the history of Alsace, geography was the one that "cast" people in history. In other words, it was the geographic position which determined the specific historical destiny of Alsatians who had to defend their territory from foreign invasions of all kinds. Not only the specific regional climate, determined by landforms, was responsible for Alsatians' way of being, but also the independent actions of people who had actively assumed the inhabited territory, protecting it. Thus, Alsace acquired the attributes not only of a paradise on earth but also of a land bathed in tears and blood. According to Ferdinand Dollinger, "The mild climate and the generosity of the land could have tended to Alsatians' easy and a bit flat existence, if it had not been for the ceaseless defense against jealousy and envy. Thus, this blessed but blood and tear-stained soil like few others produced and formed a strong race which undoubtedly does not despise to celebrate the favorable destiny, but which is more suitable for stoically suffering the worst trials and vigorously defend its personality" (Dollinger 1929: 116-117). ${ }^{19}$ On the other hand, geography and human genius have completed each other since they are two complementary and organically related entities. Finally, people have come to accept their special relationship with regional geography, understanding, assuming and loving it. Anselme Laugel claims that:

Therefore, the necessary action of nature juxtaposes the free and purposeful action of human personality. Seizing and exploiting the land, creating groups, ensuring rights, claiming freedoms, man contributes in turn to the formation of new concepts which only nature can provide. And the first concept which has been developed is the concept of love and attachment to the land and to the country whose organization had cost so much energy but which gives so many joys and, lastly, where so many prayers were arisen to heaven (Laugel 1917: 11-12). ${ }^{20}$

18 "[...] tout cela constitue comme un grand corps vivant, grouillant de réalités présentes et de souvenirs évocateurs."

19 "La douceur du climat et la générosité de la terre auraient pu incliner l'Alsacien à cette existence facile et un peu plate, s'il n'avait dû sans trêve défendre ces faveurs contre les jalousies et les convoitises. Ainsi, ce sol béni, mais trempé comme peu d'autres de sang et de larmes, a produit et façonné une forte race, qui ne dédaigne pas, sans doute, de faire fête au destin propice, mais qui se révèle plus apte encore à subir, stoïque, les pires épreuves et à défendre âprement sa personnalité [...]"

20 " [...] A l'action nécessaire de la nature, vient donc se juxtaposer l'action libre et réfléchie de la personnalité humaine. L'homme, en s'emparant du sol, et exploitant la terre, en créant des 
Vineyards constitute important elements of Alsace's inner space. The architectural monuments were presented in this waving natural setting covered with vines and bounded by the Vosges. Thus Steeples in the vineyards [Les clochers dans les vignes] became some kind of identitary terminals marking here and there the Alsatian landscape. Although the book of Hansi-alias Jean-Jacques Waltz (1873-1951), an illustrator from Colmar-, which consecrated the phrase, had a clear Francophile, even propagandistic message, Les clochers dans les vignes had in fact a strong regionalist message which was exploited as such. Most probably Hansi wanted to keep his book-in which illustration is as important as text itself-far from any kind of diverted regionalist interpretation, militating for an Alsace with French language and culture included in a unitary France. Hence, Hansi strongly opposed to regionalism, which, in his view, had been exploited for strictly political reasons. He claims:

I have seen our leaders trying to do an experiment of regionalism in one single province of France where it should not have been done and maintaining, against all odds, the fiction of an Alsace-Lorraine region which is outdated and impossible. I have seen how politicians seek to win people of Alsace to join their petty cause by ridiculous and unrealistic means; and I have seen how teaching the national language perishes in schools (Hansi 1929: 86). ${ }^{21}$

The significance of the bell tower (campanile) was of particular importance for regionalism. The Italian campanilismo derives from the root of the word campanile. In order to classify the different forms of regionalism, I gave campanilismo a new definition..$^{22}$ In the same time, in the shadow of the campanile the parochial spirit was born (the awareness of belonging to a small community: a district or a parish) as well as localism or regionalism in their larger meaning. The competition between various towns and villages is well known in art history, the aim of which is to build a more beautiful and higher church completed or crowned with a

groupements, en s'assurant des droits, en revendiquant des libertés, contribue, à son tour, à la formation de notions nouvelles que la seule nature ne peut fournir. El la première notion qui a ainsi été développée, c'est la notion de tendresse et d'attachement pour la terre dont on avait subi les influences, pour le pays dont l'organisation avait coûté tant d'énergie, où s'étaient aussi récoltées bien des joies, et d'où enfin s'étaient élevées vers le Ciel bien des prières."

21 "J'ai vu nos gouvernants tenter une expérience de régionalisme dans la seule province de France où elle ne devait pas être tentée et vouloir maintenir, envers et contre tous, la fiction d'une région périmée et impossible appelée Alsace-Lorraine. J'ai vu des politiciens chercher à gagner à leur cause mesquine les gens d'Alsace par de basses ridicules et irréalisables; et j'ai vu périe l'enseignement de la langue nationale dans les écoles du peuple."

22 In Romanian language campanilism has not been defined yet. Hence the definition I gave it is the following: a form of local or regional patriotism which encharges with a cultural assumption of the past and of the local or regional geography, involving, at the same time, the belief in the existence of a genius of the place (see Trifescu 2009: 413). 
bell tower which stands for skill and wealth. From a regionalist perspective, les clochers dans la vignes symbolized an identitary landscape marked by church towers pointing out various art and identitary local features and a well-defined, visually distinct space called artistic geography.

In 1917 Anselme Laugel—and certainly he was not the first one-noticed that Alsatian villages had grown "in the shadow" of the parish church town, taken as a reference, being surrounded (this time) by orchards. According to the Alsatian scholar, the regional unity was emphasized rather than local features. Each and every village dominated by the bell tower had been presented in the framework of an orchard which did not separate these nomadic villages since they were interwoven by a network of roads which provided the necessary connections specific to a unitary space:

Randomly scattered and discarded villages grouped around a tower surrounded by orchards and connected to each other by roads shaded by majestic walnut trees. This is the beautiful garden which Louis XIV admired when, on a beautiful summer day, he saw the top of Saverne hill sparkle, this immense area where light shade of clouds run and then disappear in a transparent, misty distance (Laugel 1917: 13-14). ${ }^{23}$

From Robert Heitz's perspective, the inner space of Alsace gained architectural dimensions being delimited by the Rhine and "the foothills of the Vosges". In fact, this closed space became a paradise garden (hortus conclusus) in which the fertility of the soil led to agricultural abundance. At the same time, the art historian from Strasbourg excluded the existence of an inner homogeneity of the Alsatian territory emphasizing, on the contrary, the infinite fragmentation of the farmlands. Heitz placed the towns and villages of Alsace in this luxurious, well-defined and peculiar landscape. From an overall perspective of the regional landscape, these villages are dominated by the bell towers which rise from the vineyards: “(...) Alongside these open villages there are fashionable half timbered white houses having their eaves full of blooming geraniums and wisteria. These and the 'Steeples in the vineyards' are the favorite topics of Alsatian imagery" (Heitz 1952: 28). ${ }^{24}$

23 “[...] Disséminés et jetés comme au hasard, les villages aux maisons groupées autour d'un clocher, sont entourées de vergers et reliés les uns aux autres par des routes qu'ombragent de majestueux noyers. C'est le beau jardin que Louis XIV admirait quand, par un beau jour d'été, il vit, du haut de la côte de Saverne, étinceler devant lui cette étendue immense où courait l'ombre légère des nuages, et qui allait se perdant dans la transparente buée d'un lointain vaporeux."

24 "[...] Les agglomérations devant à leur passé de places fortifiées l'aspect de petits villes, y côtoient les villages ouverts, aux coquettes maisons crépies de blanc, aux colombages apparents, coupées d'auvents, fleuries de géraniums et de glycines. // C'est là, avec les 'Clochers dans les vignes', le sujet de prédilection de l'imagerie alsacienne." 
As shown above, Alsatian art historians were particularly interested in problems concerning geography and the identification of natural borders defining regional space. On the other hand, the description of Alsace's inner space was an equally important concern since it determined the peculiarity of Alsatian landscape where the artistic monuments were integrated as essential parts of the specific geographic environment. In this context, 'Clochers dans les vignes' ['Steeples in the vineyards'] became "the favourite topic of Alsatian imagery", ${ }^{25}$ as Robert Heitz puts it.

Without going into the complex and controversial issue of regional and national artistic geographies, bell towers of Alsatian churches, villages and towns became regional symbols par excellence. The next step was none other than trying to nationalize them in order to define the characteristics of Alsace and to discover some affinities between this region and French or German culture. Laugel Anselme’s text, published in 1917-just like Émile Mâle’s (Mâle 1917: passim) combative piece of work-proposed a solution to this problem by adopting an active perspective determined by the impact of the Great War. Laugel claims that: "But there will come a day when we will resume this talk about the Alsatian spirit - when the Tricolor will float over all the steeples of Alsace - and I could continue my thought by adding, as you expect, that Alsatian spirit is incompatible with that of the Germans, if there is such a thing as German spirit", ${ }^{26}$ and finally concludes that Alsatians: "are essentially of French qualities" (Laugel 1917: 30-31) ${ }^{27}$ Later on, this symbolic representation of Alsace's landscape, marked here and there by steeples in the vineyards which became national items being "labelled" with the French tricolor, was continued, on every occasion, in the illustrated books of Hansi, where joyous Alsace ${ }^{28}$ was painted in French national colors. It is not by chance that the first thing the French did after they victoriously entered Alsace in November 1918 was to place a French flag on top of the spire of Strasbourg cathedral. ${ }^{29}$

[Translated by Enikő Pál]

25 "le sujet de prédilection de l'imagerie alsacienne"

26 "Mais le jour viendra où nous reprendrons cette causerie sur l'esprit alsacien - le drapeau tricolore flottera alors sur tous les clochers de l'Alsace - et je pourrais compléter ma pensée en y ajoutant les développements que vous prévoyez, et vous montrer à quel point cet esprit alsacien est incompatible avec l'esprit allemand, si toutefois il est encore permis de parler d'un esprit allemand [...]"

27 "sont aussi essentiellement des qualités françaises"

28 L'Alsace heureuse

29 Actually, the French tricolor replaced the red flag which had been placed there by a few communists who took advantage of the political situation in the first days after the armistice of November 11 which marked the end of the war. Similarly, in November 1944, the French national flag was placed again on the top of Strasbourg cathedral, as a token of victory. 


\section{References}

Ahnne, Paul. 1950. Le visage romantique de l'Alsace. Lithographies de 1815 à 1870. [The Romantic Face of Alsace. Lithographs from 1815 to 1870.] Strasbourg - Paris: Compagnie des Arts Photomécaniques.

Dollinger, Ferdinand. 1929. L'Alsace. Choix de textes précédés d'une étude. [Alsace. Selection of Texts Preceded by a Study.] Paris : Librairie Renouard, H. Laurent Éditeur.

Hallays, André. 1929. Sites et monuments. L'Alsace (le Haut-Rhin - le Bas-Rhin). [Sites and Monuments. Alsace (Haut-Rhin - Bas-Rhin).]. Paris: Touring-Club de France.

Hansi. 1929. Les clochers dans les vignes [Steeples in the Vineyards]. Paris: Librairie Floury.

Haug, Hans. 1966. Introduction. In Les Vosges alsaciennes. Nature, art, histoire [Alsatian Vosges. Nature, Art, History], VII-XXIII. Strasbourg: Éditions des Dernières Nouvelles de Strasbourg.

Heitz, Robert. 1952. L'Alsace vue par les artistes. [Alsace Seen by Artists.] Paris: Éditions des Horizons de France.

Laugel, Anselme. 1917. L'art populaire alsacien. [Alsatian Folk Art.] Paris Nancy, publiées par l'Union Amicale d'Alsace-Lorraine.

Mâle, Émile. 1917. L'art allemand et l'art français du Moyen Age. [German and French Art in the Middle Ages.] Paris: Librairie Armand Colin.

Marthelot, Pierre. 1947. Géographie humaine de l'Alsace. [Human Geography of Alsace.] In Pierre Marthelot, Philippe Dollinger, Robert Heitz, Alfred Biedermann (eds.), Visages de l'Alsace [Faces of Alsace], 93-171. Paris: Éditions des Horizons de France.

Odilé, Claude. 1934. Alsace. Paris: Éditions Alpina.

Régamey, Raymond. 1925. Introduction. In L'Art en Alsace. Exposition organisée sous le patronage de la Société des Amis des Arts de Strasbourg. [Art in Alsace. Exhibition Organized under the Patronage of the Society of Arts' Friends from Strasbourg.], 3-12. Paris: Exposition Internationale des Arts Décoratifs et Industriels Modernes [International Exhibition of Modern Decorative and Industrial Arts].

Trifescu,Valentin. 2009. Le campanilisme dans l'histoire de l'art. Hans Haug et sa conception de l'art alsacien. [Campanilism in Art History. Hans Haug and His View on Alsatian Art.] In Perspectives contemporaines sur le monde médiéval 1. [Contemporary Perspectives on the Medieval World 1], 413- 419. Piteşti: TipArg. 